\title{
Utilization of Purines by an HPRT Variant in an Intelligent, Nonmutilative Patient with Features of the Lesch-Nyhan Syndrome
}

\author{
BOHDAN BAKAY, ERKKI NISSINEN, LAWRENCE SWEETMAN, UTA FRANCKE, AND \\ WILLIAM L. NYHAN \\ Department of Pediatrics, University of California San Diego, La Jolla, California USA
}

\begin{abstract}
Summary
The patient, H.Chr.B., was among the first reported with hyperuricemia and central nervous system symptoms. He has been found to have a variant of hypoxanthine guanine phosphoribosyl transferase (HPRT; E.C.2.4.2.8) distinct from the enzyme present in patients with the Lesch-Nyhan syndrome. The patient had choreoathetosis, spasticity, dysarthric speech, and hyperuricemia. However, his intelligence was normal and he had no evidence of self-mutilation. There was no activity of HPRT in the lysates of erythrocytes and cultured fibroblasts when analyzed in the usual manner. Using a newly developed method for the study of purine metabolism in intact cultured cells, this patient was found to metabolize some $9 \%$ of $8^{-14} \mathrm{C}$-hypoxanthine, and $90 \%$ of the isotope utilized was converted to adenine and guanine nucleotides. In contrast, cells from patients with the Lesch-Nyhan syndrome were virtually completely unable to convert hypoxanthine to nucleotides. The patient's fibroblasts were even more efficient in the metabolism of $8-{ }^{14} \mathrm{C}$-guanine, which was utilized to the extent of $27 \%$, over $80 \%$ of which was converted to guanine and adenine nucleotides. The growth of the cultured fibroblasts of this patient was intermediate in media containing hypoxanthine aminopterin thymidine (HAT), whereas the growth of Lesch-Nyhan cells was inhibited and normal cells grew normally. Similarly in 8-azaguanine, 6thioguanine, and 8-azahypoxanthine, the growth of the patient's cells was intermediate between normal and Lesch-Nyhan cells. These observations provide further evidence for genetic heterogeneity among patients with disorders in purine metabolism involving the HPRT gene. They document that this famous patient did not have the Lesch-Nyhan syndrome.
\end{abstract}

\section{Speculation}

Self-mutilation is a uniform feature of the Lesch-Nyhan syndrome, and the phenotype includes a variant HPRT that has virtually no activity under any conditions of assay. Inherited variation of the gene that codes for the synthesis of HPRT may be considerable. Different variants may produce clinically distinct phenotypes.

In patients with the Lesch-Nyhan syndrome, there is a virtually complete deficiency of the catalytic activity of HPRT; E.C.2.4.2.8 $(17,28)$. In the presence of this molecular abnormality, the patient has hyperuricemia, choreoathetosis, spasticity, developmental retardation, and characteristic compulsive self-mutilation by biting (17). In contrast, patients with partial deficiencies of this enzyme have hyperuricemia, and they may have renal stone disease or gout, but they seldom have abnormalities of the central nervous system $(14,16,29,30)$. Patients with partial deficiency of HPRT may have up to $50 \%$ of normal HPRT activity $(9,10,13,15,26$, 29,30). Some may have disparate deficiency of HPRT in different cell types $(9,13)$. A number of variant HPRT enzymes have been shown to have altered kinetic, electrophoretic, or immunochemical properties $(2,4,5,7,15,21,23,29,30,33)$, and whenever a deficiency of HPRT has been found, there has been an identifiable clinical abnormality (22).

There has been no clear correlation between the properties of the variant HPRT and the clinical phenotype (10). On the other hand, the classic Lesch-Nyhan syndrome occurs in patients with virtually complete deficiency of HPRT. The authors believed that self-mutilation was an integral part of the syndrome, yet this point of view has not been uniformly held (26). The patient first reported by Catel and Schmidt (8) and more recently by Manzke and associates (18-20) has been cited as an important example of the Lesch-Nyhan syndrome patient in whom the activity of HPRT was virtually zero, but who had normal intelligence and normal behavior.

The authors' studies of HPRT in erythrocytes failed to distinguish this patient from patients with the classic Lesch-Nyhan syndrome. However, using a method of purine analysis recently developed in these laboratories (3), it has been found that intact skin fibroblasts derived from this patient were unlike those of patients with the Lesch-Nyhan syndrome in that they were able to utilize both purine substrates. They utilized $8-{ }^{4} \mathrm{C}$-guanine considerably more efficiently than $8-^{14} \mathrm{C}$-hypoxanthine.

\section{CASE REPORT}

H.Chr.B. $(8,18-20)$ was 22 -yr-old at the time of this study. He had been born, uneventfully, weighing $4500 \mathrm{~g}$. At 6 months, he began to have repeated fevers and appeared to have psychomotor retardation. At 18 months, he was admitted to the University Hospital in Kiel, Germany. He was hypotonic and could not sit or stand by himself. He could lift his head in the prone position, but had no words. Uric acid crystals were repeatedly found in the diapers and the concentration of his serum uric acid was elevated and, at one point, rose to $15.5 \mathrm{mg} / \mathrm{dl}$. He had athetoid movements and developed dysarthric speech. Over the next 18 months, he learned to sit and to stand with support and to swallow solid food. His intelligence appeared appropriate for his age.

When discharged from the hospital, he did not return to his family in South America, but remained in a school for handicapped children in Germany. He was observed to have macrocytic anemia which disappeared when he was treated with allopurinol at the age of $11 \mathrm{yr}$. He never self-mutilated. At the age of 18 , he finished high school with good grades. He had hematuria lasting I wk at 19 yr of age.

At $20 \mathrm{yr}$ of age, H.Chr.B. was living in a rehabilitation center in Germany, and was attending a junior college with a major in Science. He was living in a dormitory with other handicapped young adults. He was of normal height, well nourished, and had normal muscular development. He was confined to a wheelchair, but could move about independently. He could walk with assistance. When passively listening, he was able to control his cho- 
reoathetosis perfectly. But his neurologic abnormality became obvious as soon as he talked or moved. He had dysarthric speech, but his vocabulary appeared normal. He could write legibly, but it required a major effort and a long time. His hair was sparse making him appear older than his chronologic age. There were no physical abnormalities or evidence of self-mutilation. He stated that he had never had any desire to mutilate. His personality was outgoing.

He was receiving $300 \mathrm{mg}$ of allopurinol each day on which regimen his uric acid concentration was between $4-6 \mathrm{mg} / \mathrm{dl}$.

Hair roots from two sisters, M. and N., were analyzed in our laboratory (11). M. had 23 hair roots in which HPRT was in the normal range and she was diagnosed as homozygous normal. $\mathbf{N}$. had 14 hair roots in which HPRT was within normal range and 7 hair roots in the intermediate range; none of her hair roots were completely negative. These results are characteristic of heterozygosity for a defect in HPRT in which there is partial deficiency of activity.

A maternal uncle died at the age of $20 \mathrm{yr}$ from sepsis related to an infected tophus. This male had had tophaceous gout, severe spastic tetraplegia, choreoathetosis, dysarthria, gouty arthritis, and no self-mutilation. The concentrations of uric acid in his serum were between $8.9-10.4 \mathrm{mg} / \mathrm{dl}$. He also had anemia and polyuria and a lack of ability to concentrate the urine. The maternal grandmother had three brothers that were severely retarded.

\section{MATERIALS AND METHODS}

\section{BLOOD CELLS AND LYSATES}

Venous blood was drawn into tubes containing heparin or acid citrate-dextrose solution, which were hand carried or sent by the fastest route to this laboratory from Germany. Red blood cells were washed 3 times in $0.01 M$ Tris- $\mathrm{HCl}$ containing $0.1 \mathrm{M} \mathrm{KCl}$

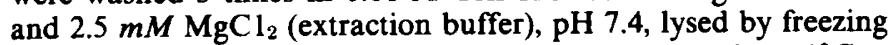
in 9 volumes of cold E.X. buffer and centrifuged $20 \mathrm{~min}$ at $4^{\circ} \mathrm{C}$ at $48,000 \times g$

\section{FIBROBLASTS AND LYSATES}

Fibroblasts derived from skin biopsied from normal individuals, patients with the Lesch-Nyhan syndrome (L.N.), and H.Chr.B. were grown in Eagle's Minimal Essential Medium (MEM) containing glutamine, $100 \mathrm{U}$ penicillin/ml, and $100 \mu \mathrm{g}$ streptomycin/ $\mathrm{ml}$, and $10 \%$ fetal calf serum. The cells were harvested in late log phase by brief treatment with trypsin-EDTA solution (ATV). For enzyme analysis, they were washed in E.X. buffer, resuspended in the same buffer to a density of $10^{7}$ cells $/ \mathrm{ml}$, lysed by 4 cycles of freezing and thawing, and centrifuged $20 \mathrm{~min}$ at $4^{\circ} \mathrm{C}$ at $48,000 \times$ g.

\section{UTILIZATION OF RADIOACTIVE PURINES}

For studies on utilization of purines, fibroblasts were grown in MEM in roller bottles. The bottles were seeded with $6 \times 10^{6}$ cells and harvested when they grew to $24 \times 10^{6}$ (two doublings). The cells were promptly washed once in MEM and once in either 0.05 $M$ sodium phosphate $\mathrm{pH} 7.4$ buffer containing $0.1 \mathrm{M} \mathrm{NaCl}$ and $0.1 \%(\mathrm{w} / \mathrm{v})$ glucose (PBSG) or modified Krebs-Ringer solution containing $0.125 \mathrm{M} \mathrm{NaCl}, 4.95 \mathrm{mM} \mathrm{KCl}, 1.25 \mathrm{mM} \mathrm{MgSO}_{4}, 16$ $m M \mathrm{Na}_{2} \mathrm{HPO}_{4}, 0.1 \%(\mathrm{w} / \mathrm{v})$ glucose, and $4 \mathrm{mg} / \mathrm{ml}$ human serum albumin, pH 7.4, and counted in a Coulter counter. After brief centrifugation at low speed, pelleted cells were resuspended in either PBSG at $2 \times 10^{6} \mathrm{cells} / \mathrm{ml}$ or in modified Krebs-Ringer solution at $4 \times 10^{6}$ cells $/ \mathrm{ml}$, transferred to Falcon flasks, and incubated in a shaking water bath regulated at $37^{\circ} \mathrm{C}$. After $15 \mathrm{~min}$ preincubation, $2 \mu \mathrm{C} / \mathrm{ml}$ of $8-{ }^{14} \mathrm{C}$-hypoxanthine (specific activity $42.4 \mathrm{mC} / \mathrm{mM}$ ), $8-{ }^{14} \mathrm{C}$-guanine (specific activity $43.1 \mathrm{mC} / \mathrm{mM}$ ), 8${ }^{14} \mathrm{C}$-adenine (specific activity $43.9 \mathrm{mC} / \mathrm{mM}$ ), or ${ }^{14} \mathrm{C}$-formate (specific activity $60 \mathrm{mC} / \mathrm{mM}$ ) were added to the flask. Incubation was continued for $2 \mathrm{hr}$ and the flasks were placed on ice. Cell suspensions were transferred into plastic centrifuge tubes and centrifuged $10 \mathrm{~min}$ at $4^{\circ} \mathrm{C}$ at $400 \times \mathrm{g}$. After removal of the supernatant fluid, the cells were suspended in $100 \mu \mathrm{l}$ of ice cold $0.8 \mathrm{M} \mathrm{HClO}_{4}$ using Vortex mixer, extracted $10 \mathrm{~min}$, and centrifuged $20 \mathrm{~min}$ at $4^{\circ} \mathrm{C}$ at $48,000 \times \mathrm{g}$. The supernatant fluids were transferred into plastic centrifuge tubes, neutralized with $\mathrm{KOH}$ to $\mathrm{pH} 8$, and centrifuged $2 \mathrm{~min}$ at $25,000 \times \mathrm{g}$. The supernatant fluids were separated and used for the chromagraphic analysis of purines and metabolites using the method previously described (3).

In the course of these studies, it became apparent that there was considerable variation in the cell size and that the cell count and protein content of different cultured skin fibroblasts varied widely. Because of this variation, the expression of incorporated or metabolized precursors per cell count or $\mathrm{mg}$ protein yielded inconsistent data. Better agreement between experiments was obtained when the collected values were expressed in terms of the total acid soluble ultraviolet absorbing material (uv) as measured by the uv detector. Consequently, the data have been expressed as picomoles of ${ }^{14} \mathrm{C}$ components/nanomole uv components ( $\mathrm{pM}{ }^{14} \mathrm{C} / \mathrm{nM} \mathrm{uv}$ ).

\section{GROWTH OF CELLS IN 8-AZAGUANINE, 8-AZAHYPOXANTHINE, 6-} THIOGUANINE, AND HAT MEDIA

Three types of cells, normal, L.N. and H.Chr.B., were plated in 20 dishes each in MEM. After the cells attached to the dishes, MEM was replaced with HAT medium or MEM containing different concentrations of 8-azaguanine, 8-azahypoxanthine, or 6 -thioguanine $(31,32)$. Cells grown in HAT medium were harvested and counted in a Coulter counter on days $1,4,6,9$, and 12 . Cells grown in other media were harvested and counted after 72 hr of incubation.

\section{ASSAY OF HPRT ACTIVITY}

The activity of HPRT in hemolysates was determined by radiochemical assay using $\mathrm{LaCl}_{3}(6)$. The activity of HPRT in fibroblasts was determined in the presence of $\alpha, \beta$-methylene-adenosine-5'-diphosphate an inhibitor of 5 -nucleotidase using $\mathrm{LaCL}_{3}$ precipitation method (6), or chromatographic method (3) for the detection of inosine monophosphate (IMP). In the presence of $\alpha, \beta$-methylene-adenosine- $5^{\prime}$-diphosphate, inosine was not formed from IMP. HPRT was also studied using electrophoretic analysis (1).

\section{REACTION OF HPRT WITH ANTI-HPRT IMMUNOGLOBULIN}

The cell lysates of normal individuals were reacted with antibodies against normal HPRT in the presence and absence of lysates prepared from HPRT deficient cells and examined for HPRT activity (2). The presence of enzymatically incompetent, but immunochemically competent HPRT enzyme protein was calculated from the difference in HPRT activity. The test was sufficiently sensitive to detect $2 \%$ change in activity.

\section{RESULTS}

\section{HPRT ACTIVITY OF HEMOLYSATES AND FIBROBLAST LYSATES}

Assay of HPRT was carried out on one occasion on hemolysates prepared from cells of 4-day-old and in another, from 6-day-old samples drawn from H.Chr.B. The first sample was hand carried from Germany and the second was sent in heparin by mail. Assay at 37 and $60^{\circ} \mathrm{C}$ at $0.01 \mathrm{mM}$ hypoxanthine and $1 \mathrm{mM}$ PRPP showed a total absence of HPRT activity. However, at $0.375 \mathrm{mM}$ hypoxanthine and $1 \mathrm{mM}$ PRPP concentration, the same lysate contained at $37^{\circ} \mathrm{C} 48 \%$ and at $60^{\circ} \mathrm{C} 52 \%$ of normal HPRT activity. Similar results were obtained with guanine as substrate.

When the HPRT analysis was repeated on fresh hemolysates prepared from cells of 10-day-old sample using 0.01-0.4 $\mathrm{mM}$ hypoxanthine and $1 \mathrm{mM}$ PRPP concentration, no activity was detectable.

Assays of HPRT were performed using lysates of cultured fibroblasts derived from H.Chr.B. at low and high concentrations of both hypoxanthine and guanine, but no activity was present. HPRT activity was also absent in hemolysates and fibroblast lysates when tested by the electrophoretic method of analysis (1). 
When tested by competitive immunoprecipitation, hemolysates and fibroblast lysates of H.Chr.B. contained no crossreacting material.

\section{UTILIZATION OF "C-LABELED PRECURSORS}

The metabolism of ${ }^{14} \mathrm{C}$-labeled formate, adenine, guanine, and hypoxanthine was studied in cultured skin fibroblasts derived from H.Chr.B., normal individuals, and three patients with the classical Lesch-Nyhan syndrome. In addition, the cells of a patient with $3 \%$ of normal HPRT were studied (30).

The overall incorporation of the different precursors into the acid extract of human cells is shown in Table 1. HPRT-deficient cells derived from H.Chr.B. as well as T.L. and the three L.N. patients, utilized 1.7, 5.7, and 2.1 times as much formate as normal cells, respectively. These data indicate that HPRT-deficient cells have an accelerated rate of biosynthesis of purine de novo.

The utilization of $8-{ }^{14} \mathrm{C}$-adenine by L.N. and T.L. cells and the cells of H.Chr.B. was elevated over the amount utilized by the normal cells, 1.2-1.5 times. This increase in the utilization of adenine is inconsistent with an elevated level of APRT activity.

The experiments with guanine have shown that H.Chr.B. utilized $26.5 \%$ of $8-{ }^{14} \mathrm{C}$-guanine utilized by normal cells, while L.N. utilized $12.5 \%$ of the normal value (Table 1). Similarly, H.Chr.B. utilized $9 \%$, while L.N. cells utilized only $6 \%$ of the $8-{ }^{14} \mathrm{C}$-hypoxanthine utilized by the normal cells.

\section{METABOLISM OF 8. ${ }^{14} \mathrm{C} \cdot$ HYPOXANTHINE}

The data obtained with $8-{ }^{14} \mathrm{C}$-hypoxanthine as the precursor are shown in Table $2 \mathrm{~A}$. In the extracts of normal cells, there was 22 uv-absorbing components of which 16 were radioactive. Because acid extracts were prepared without washing the cells, it was likely that considerable amounts of labeled precursors were carried over and included in the acid extracts. Hence, in experiments with labeled adenine, guanine, and hypoxanthine, the respective bases were excluded from the calculations.

In all three cell types, adenine nucleotide pools always constituted the largest fraction of uv-absorbing materials. Guanine nucleotides constituted the next largest fraction, and nucleosides and purine bases constituted the smallest fraction. With hypoxanthine as the precursor, as much as $\mathbf{8 0 \%}$ of the isotope did accumulate in adenine nucleotides, $11 \%$ in guanine nucleotides, and $8 \%$ in inosine. Among the adenine nucleotides, adenosine triphosphate (ATP) contained the largest amount of isotope.

By comparison, L.N. cells utilized a very small amount of 8${ }^{14} \mathrm{C}$-hypoxanthine of which more than $53 \%$ was converted to inosine, and only $33 \%$ was converted to adenine and guanine nucleotides. This indicated virtually total inability of HPRT of the L.N. cells to utilize hypoxanthine.

The amount of hypoxanthine utilized by H.Chr.B. cells was also considerably smaller than in the normal cells, but it was larger than in L.N. cells. Further, about $46 \%$ of the isotope of hypoxan- thine was metabolized to adenine nucleotides, $15 \%$ to guanine nucleotides and $34 \%$ to inosine. The data indicate that H.Chr.B. had an HPRT with limited capability for processing hypoxanthine.

\section{METABOLISM OF $8{ }^{14} \mathrm{C}-$ GUANINE}

Acid extracts of normal cells incubated with $8-{ }^{14} \mathrm{C}$-guanine contained 20-22 uv-absorbing components of which 16 were identified to be purines or derivatives. Fifteen components were radioactive, but only 14 were purine metabolites.

In the normal cells, about $85 \%$ of $8-{ }^{14} \mathrm{C}$-guanine was converted to guanine nucleotides and about $3 \%$ to adenine nucleotides (Table 2B). The rest of the isotope was in nucleosides and bases. Although a small amount of xanthosine was present, xanthine, and xanthosine monophosphate were absent.

In cells of the L.N. patients, $76 \%$ of the $8-{ }^{14} \mathrm{C}$-guanine metabolized was found in guanosine and $17 \%$ was found in nucleotides.

In contrast, in the cells of H.Chr.B., $78 \%$ of $8 .{ }^{14} \mathrm{C}$-guanine utilized was used for the synthesis of guanine nucleotides, $17 \%$ for synthesis of guanosine and 3\% for synthesis of adenine nucleotides. Thus, in the intact cells derived from H.Chr.B., HPRT was considerably more efficient in the handling of guanine than was the HPRT of L.N. cells. This suggests that the kinetic properties of HPRT of H.Chr.B. and L.N. cells were distinctly different.

\section{METABOLISM OF $8.14 \mathrm{C} \cdot \mathrm{ADENINE}$}

The utilization of $8{ }^{14} \mathrm{C}$-adenine is shown in Table $2 \mathrm{C}$. In all three cell types, over $85 \%$ of the isotope was in adenine nucleotides and slightly more than $2 \%$ in guanine nucleotides. About $50 \%$ or over was in ATP. Adenosine diphosphate (ADP) contained 15$26 \%$ and adenosine monophosphate (AMP) contained 5-15\%. With the exception of inosine, all other nucleosides contained a very small fraction of isotope. In the extracts of normal cells, hypoxanthine contained about $2 \%$ of the isotope, but hypoxanthine of H.Chr.B. and L.N. cells contained 5 and $6 \%$, respectively.

\section{SPECIFIC ACTIVITIES OF METABOLITES}

The specific activities $(\mathrm{nCi} / \mathrm{nM})$ of the various purine metabolites are shown in Table 2 . Among the radioactive components, the specific activities of the purine bases, e.g., guanine in the experiment with $8-{ }^{14} \mathrm{C}$-guanine, were considerably higher than of other metabolites. The component with the next highest specific activity in experiments with guanine was guanosine, whereas in experiments with hypoxanthine, it was inosine. This indicated that purine nucleoside phosphorylase was highly active in these cells. Incubation with guanine led to relatively high specific activity of guanine nucleotides, and incubation with hypoxanthine and adenine led to relatively high specific activity of adenine nucleotide pools. In cells deficient in HPRT activity, especially L.N. cells, the specific activities of nucleotides were extremely low.

A virtual absence of xanthine metabolites and adenylosuccinate

Table 1. Utilization of ${ }^{14} \mathrm{C}$ of purine precursors in cultured cells

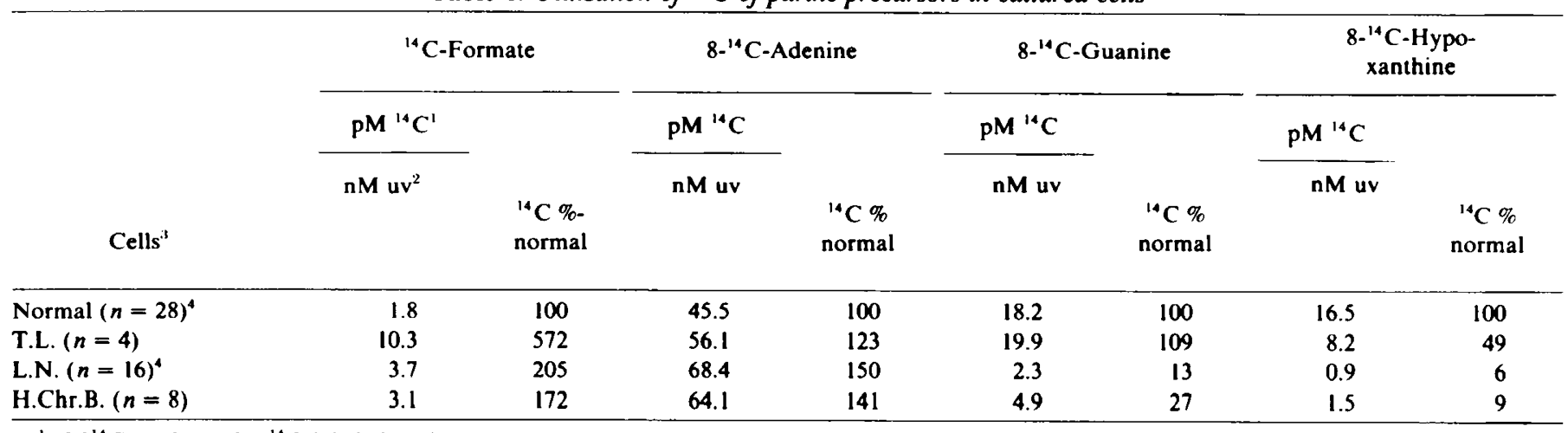

${ }^{1} \mathrm{pM}^{14} \mathrm{C}=$ picomoles ${ }^{14} \mathrm{C}$-labeled purine metabolites.

${ }^{2} \mathrm{nM}$ uv = nanomoles purine metabolites.

${ }^{3} \mathbf{n}=$ number of analyses.

${ }^{4}$ The experiments with different precursors were carried out on 3-7 normal individuals or L.N. patients (See Table 2). 
Table 2. Distribution of purine metabolites in acid extracts of cultured cells

\begin{tabular}{|c|c|c|c|c|c|c|c|c|c|c|c|c|}
\hline \multirow{3}{*}{$\begin{array}{l}\text { Purine } \\
\text { Metabo- } \\
\text { lite }\end{array}$} & \multicolumn{4}{|c|}{ NORMAL } & \multicolumn{4}{|c|}{ L.N. } & \multicolumn{4}{|c|}{ H.Chr.B. } \\
\hline & \multicolumn{4}{|c|}{$\mathrm{N}=6 \quad n=8$} & \multicolumn{4}{|c|}{$\mathrm{N}=4 \quad n=10$} & \multicolumn{4}{|c|}{$\mathrm{N}=1 \quad n=2$} \\
\hline & $\mathrm{nM}$ uv & $\mathrm{pM}{ }^{14} \mathrm{C}$ & $\%$ & $\mathrm{nCi} / \mathrm{nM}$ & $\mathrm{nM}$ uv & $\mathrm{pM}^{14} \mathrm{C}$ & $\%$ & $\mathrm{nCi} / \mathrm{nM}$ & $\mathrm{nM}$ uv & $\mathrm{pM}^{14} \mathrm{C}$ & $\%$ & $\mathrm{nCi} / \mathrm{nM}$ \\
\hline \multicolumn{13}{|c|}{ Cells incubated with $8-{ }^{14} \mathrm{C}$-hypoxanthine $\mathrm{e}^{1,2}$} \\
\hline A & 4.6 & 15.7 & 0.9 & 0.39 & 1.7 & 4.1 & 4.4 & 0.03 & 1.8 & 0 & 0 & 0 \\
\hline AR & 0.1 & 3.9 & 0.2 & 1.79 & 0.1 & 3.4 & 3.6 & 0.77 & 0 & 7.1 & 4.6 & 0 \\
\hline AMP & 7.2 & 127.6 & 7.7 & 1.44 & 5.0 & 3.4 & 3.6 & 0.02 & 1.3 & 8.0 & 5.2 & 0.73 \\
\hline $\mathrm{ADP}$ & 14.1 & 238.9 & 14.5 & 0.70 & 12.4 & 6.2 & 6.7 & 0.02 & 7.3 & 22.3 & 14.4 & 0.05 \\
\hline ATP & 43.1 & 911.1 & 55.1 & 0.80 & 43.4 & 10.5 & 11.3 & 0.02 & 60.4 & 41.1 & 26.6 & 0.03 \\
\hline$(\mathrm{Hx})^{3}$ & $(3.0)$ & & & $(6.38)$ & $(2.7)$ & & & $(8.69)$ & $(6.3)$ & & & $(4.64)$ \\
\hline IR & 2.3 & 132.1 & 8.0 & 2.72 & 2.2 & 49.7 & 53.7 & 2.91 & 0.6 & 52.5 & 33.9 & 3.76 \\
\hline IMP & 0.1 & 17.2 & 1.0 & 0.38 & 3.5 & 2.9 & 3.2 & 0 & 0 & 0 & 0 & 0 \\
\hline $\mathrm{X}$ & 0 & 0 & 0 & 0 & 0 & 0 & 0 & 0 & 0 & 0 & 0 & 0 \\
\hline XR & 0 & 2.2 & 0.1 & 0 & 0 & 0 & 0 & 0 & 0 & 0 & 0 & 0 \\
\hline XMP & 0 & 7.8 & 0.5 & 0 & 0 & 0 & 0 & 0 & 0 & 0 & 0 & 0 \\
\hline $\mathrm{G}$ & 1.6 & 3.2 & 0.2 & 0.19 & 1.0 & 0 & 0 & 0 & 1.1 & 0 & 0 & 0 \\
\hline GR & 1.1 & 3.9 & 0.2 & 0.22 & 0.8 & 1.7 & 1.9 & 0 & 0.4 & 0.3 & 0.2 & 0 \\
\hline GMP & 5.7 & 21.7 & 1.3 & 0.19 & 6.1 & 1.0 & 1.1 & 0.01 & 3.7 & 3.2 & 2.1 & 0.06 \\
\hline GDP & 11.2 & 44.7 & 2.7 & 0.19 & 12.2 & 6.3 & 6.8 & $<0.01$ & 11.8 & 5.8 & 3.3 & 0.01 \\
\hline GTP & 8.9 & 122.9 & 7.4 & 0.52 & 10.7 & 3.4 & 3.7 & 0.02 & 11.7 & 15.0 & 9.7 & 0.05 \\
\hline Total & 100.0 & 1652.9 & 100.0 & & 100.0 & 92.6 & 100.0 & & 100.0 & 154.7 & 100.0 & \\
\hline \multicolumn{13}{|c|}{ Cells incubated with $8-^{14} \mathrm{C}$-guanine } \\
\hline & & $\mathbf{N}=7$ & $n=8$ & & & $N=3$ & $n=6$ & & & $\mathbf{N}=1$ & $n=3$ & \\
\hline A & 2.7 & 3.1 & 0.2 & 0.08 & 2.7 & 6.7 & 2.9 & 0.16 & 0.7 & 2.4 & 0.5 & 0.20 \\
\hline AR & $<0.1$ & 2.6 & 0.1 & 1.72 & 1.7 & 2.9 & 1.3 & 1.39 & $<0.1$ & 2.4 & 0.5 & 0.56 \\
\hline AMP & 10.2 & 7.7 & 0.4 & 0.04 & 5.8 & 4.1 & 1.8 & 0.01 & 2.5 & 3.9 & 0.8 & 0.35 \\
\hline ADP & 14.4 & 10.1 & 0.6 & 0.03 & 13.3 & 3.9 & 1.7 & 0.01 & 7.2 & 3.2 & 0.7 & 0.05 \\
\hline ATP & 34.0 & 34.0 & 1.9 & 0.05 & 38.6 & 19.9 & 8.7 & 0.01 & 40.3 & 7.9 & 1.6 & 0.01 \\
\hline $\mathrm{Hx}$ & 2.0 & 5.2 & 0.3 & 0.80 & 1.8 & 0.9 & 0.4 & 0.05 & 0.6 & 0.4 & 0.1 & 0.05 \\
\hline IR & 3.9 & 14.2 & 0.8 & 0.56 & 3.9 & 2.8 & 1.2 & 0.11 & 0.7 & 1.6 & 0.3 & 1.31 \\
\hline IMP & 2.9 & 10.7 & 0.6 & 0.14 & 3.0 & 0 & 0 & 0 & 5.3 & 1.3 & 0.3 & 0.01 \\
\hline $\mathrm{X}$ & 0 & 0 & 0 & 0 & 0 & 0 & 0 & 0 & 0 & 0 & 0 & 0 \\
\hline $\mathrm{XR}$ & 0.5 & 0.5 & $<0.1$ & 0 & 0 & 0 & 0 & 0 & 0 & 0 & 0 & 0 \\
\hline XMP & 0 & 0 & 0 & 0 & 0 & 0 & 0 & 0 & 0 & 0 & 0 & 0 \\
\hline$(G)^{3}$ & (3.5) & & & $(5.73)$ & (1.7) & & & $(8.83)$ & (1.4) & & & (11.33) \\
\hline GR & 2.6 & 190.7 & 10.4 & 3.43 & 1.4 & 174.6 & 76.1 & 7.84 & 1.1 & 83.0 & 17.0 & 2.84 \\
\hline GMP & 6.7 & 289.5 & 15.9 & 1.62 & 5.7 & 1.6 & 0.8 & 0.01 & 4.9 & 10.3 & 2.1 & 0.07 \\
\hline GDP & 12.8 & 399.4 & 21.9 & 1.51 & 16.2 & 2.7 & 1.2 & $<0.01$ & 17.4 & 45.6 & 9.4 & 0.12 \\
\hline GTP & 8.0 & 856.6 & 46.9 & 4.13 & 7.3 & 9.0 & 3.3 & 0.05 & 19.1 & 325.8 & 66.8 & 1.49 \\
\hline Total & 100.0 & 1824.3 & 100.0 & & 100.0 & 229.0 & 100.0 & & 100.0 & 487.7 & 100.0 & \\
\hline \multicolumn{13}{|c|}{ Cells incubated with $8-{ }^{14} \mathrm{C}$-adenine } \\
\hline & & $\mathrm{N}=4$ & $n=4$ & & & $N=4$ & $n=4$ & & & $\mathbf{N}=1$ & $n=1$ & \\
\hline$(A)^{3}$ & (3.4) & 0 & 0 & $(6.55)$ & (1.7) & 0 & 0 & (1.67) & (3.9) & 0 & 0 & 5.81 \\
\hline $\mathrm{AR}$ & $<0.1$ & 3.2 & $<0.1$ & 0 & $<0.1$ & 9.8 & 0.1 & 0 & 0 & 6.0 & 0.1 & 0 \\
\hline AMP & 6.8 & 229.3 & 5.0 & 3.88 & 9.5 & 999.0 & 14.6 & 5.07 & 9.4 & 816.5 & 12.8 & 3.81 \\
\hline ADP & 10.3 & 659.0 & 14.5 & 2.53 & 16.4 & 1427.9 & 20.9 & 3.01 & 18.0 & 1645.3 & 25.7 & 4.03 \\
\hline ATP & 57.2 & 3359.2 & 73.7 & 3.30 & 42.0 & 3440.4 & 50.3 & 3.62 & 35.4 & 3261.5 & 50.9 & 4.05 \\
\hline$H x$ & 1.9 & 109.2 & 2.4 & 2.17 & 3.9 & 413.9 & 6.1 & 3.71 & 3.9 & 296.3 & 4.6 & 3.33 \\
\hline IR & 0.7 & 57.1 & 1.2 & 3.18 & 2.2 & 255.0 & 3.7 & 3.17 & 2.0 & 189.8 & 2.9 & 4.19 \\
\hline IMP & 0.9 & 13.8 & 0.3 & 1.36 & 2.3 & 107.8 & 1.6 & 0.67 & 6.9 & 61.9 & 1.0 & 0.39 \\
\hline $\mathrm{X}$ & 0 & 0 & 0 & 0 & 0 & 6.8 & 0.1 & 0 & 0 & 0 & 0 & 0 \\
\hline XR & 0 & 0 & 0 & 0 & 0 & 0 & 0 & 0 & 0 & 0 & 0 & 0 \\
\hline XMP & 0 & 12.0 & 0.3 & 0 & 0 & 0 & 0 & 0 & 0 & 0 & 0 & 0 \\
\hline GR & 0.6 & 2.7 & $<0.1$ & 0 & 0 & $\begin{array}{l}0 \\
0\end{array}$ & 0 & & & 0 & 0 & \\
\hline GMP & 3.1 & 4.3 & $<0.1$ & 0.04 & 5.1 & 18.3 & 0.3 & $\begin{array}{l}0 \\
0.24\end{array}$ & $\begin{array}{l}0 \\
6.6\end{array}$ & $\begin{array}{l}0 \\
9.1\end{array}$ & $\begin{array}{l}0 \\
0.1\end{array}$ & $\begin{array}{l}0 \\
0.06\end{array}$ \\
\hline GDP & 9.2 & 24.0 & 0.5 & 0.13 & 10.6 & 49.7 & 0.7 & 0.16 & 10.5 & 43.7 & 0.7 & 0.18 \\
\hline GTP & 8.6 & 77.9 & 1.7 & 0.50 & 7.3 & 111.5 & 1.6 & 0.55 & 6.3 & 74.0 & 1.2 & 0.52 \\
\hline Total & 100.0 & 4554.8 & 100.0 & & 100.0 & 6839.8 & 100.0 & & 100.0 & 6404.0 & 100.0 & \\
\hline
\end{tabular}

${ }^{1} \mathrm{~N}=$ number of patients.

${ }^{2} n=$ number of determinations.

${ }^{3}$ Labeled hypoxanthine, guanine and adenine may represent extra cellular precursor carried over on the cell surface. 
suggest that conversion of IMP to guanosine monophosphate (GMP) and IMP to AMP proceeded at very high rates.

\section{EFFECT OF PURINE ANALOGS AND HAT ON GROWTH RATES}

The growth rates of three cell types in selective media are shown in Figure 1. In normal medium, cells of H.Chr.B. and other cell lines displayed similar rates of growth. In HAT medium, the growth of the normal cells was the same as in normal medium. The growth of the L.N. cells in HAT was virtually completely inhibited. The growth rate of H.Chr.B. cells in HAT medium was intermediate between the other two cell types.

In the presence of 8-azaguanine, 8-azahypoxanthine, and 6thioguanine, growth of normal cells was suppressed $80-100 \%$. In fact, in the medium containing 6-thioguanine, the normal cells began to die. The same three purine analogs had essentially no effect on the growth of L.N. cells but they had a strong inhibitory effect on growth of H.Chr.B. cells. Hence, in the presence of 8azaguanine, 6-thioguanine, and especially 8-azahypoxanthine, cells of H.Chr. B. grew with faster rates than normal cells but much slower than L.N. cells.

\section{A}
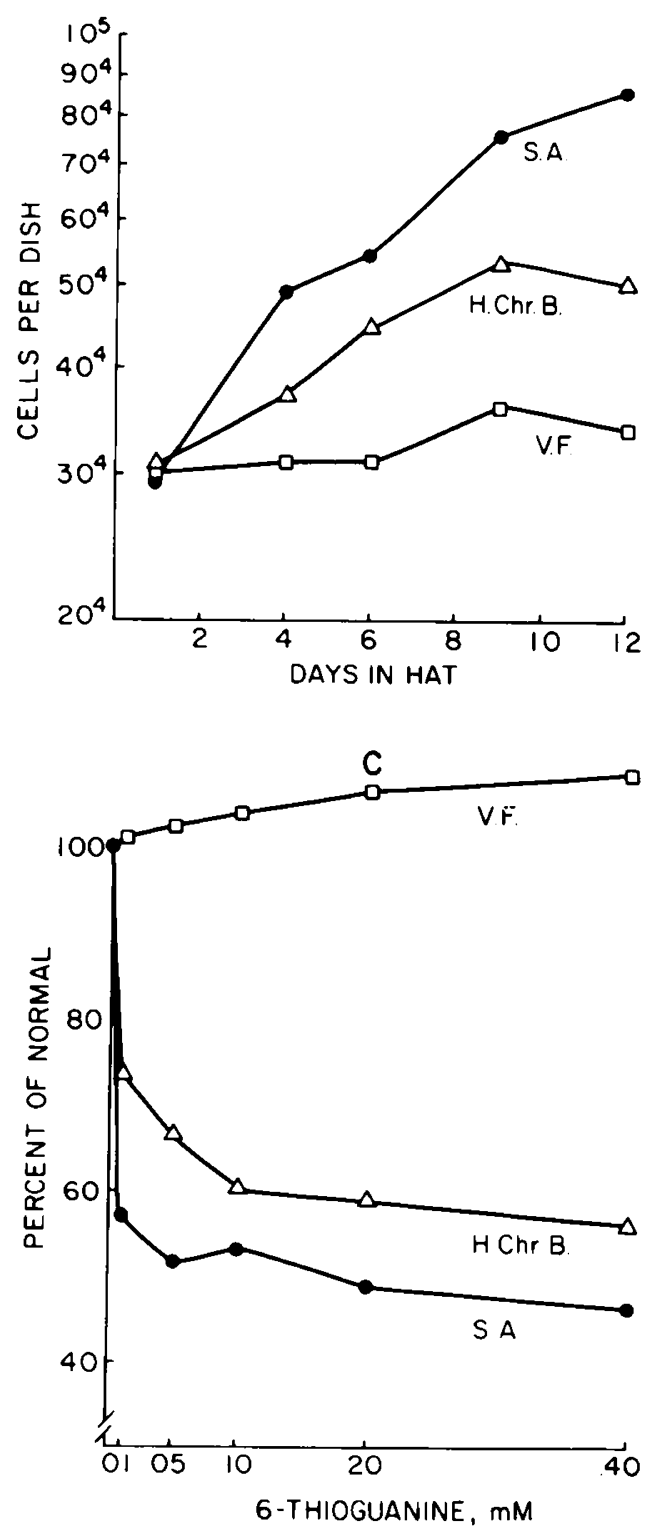

\section{DISCUSSION}

A number of variants have now been described in man in all of whom there has been some expression of the abnormal gene. In general, the clinical phenotypes can be divided into two groups: those with significant abnormalities of the central nervous system and virtually complete deficiency of HPRT, and those without cerebral abnormalities and partial deficiency of HPRT. While it has been impossible to make direct correlations between the amount of enzyme activity detected and the severity of the clinical phenotype (10), and very low activity under the usual conditions of assay has been seen without cerebral manifestations (30), there has been a generally good correlation with these broad categorizations. Both groups of patients may have any of the renal or other manifestations directly related to uric acid and seen in a patient with gout. The degree of abnormality of the central nervous system is exemplified by the patients with the LeschNyhan syndrome (18) in which the phenotype includes athetoid cerebral palsy so incapacitating that the patient can neither walk nor sit unsupported, severe retardation of mental development, and aggressive, usually self-mutilative behavior. There may be a
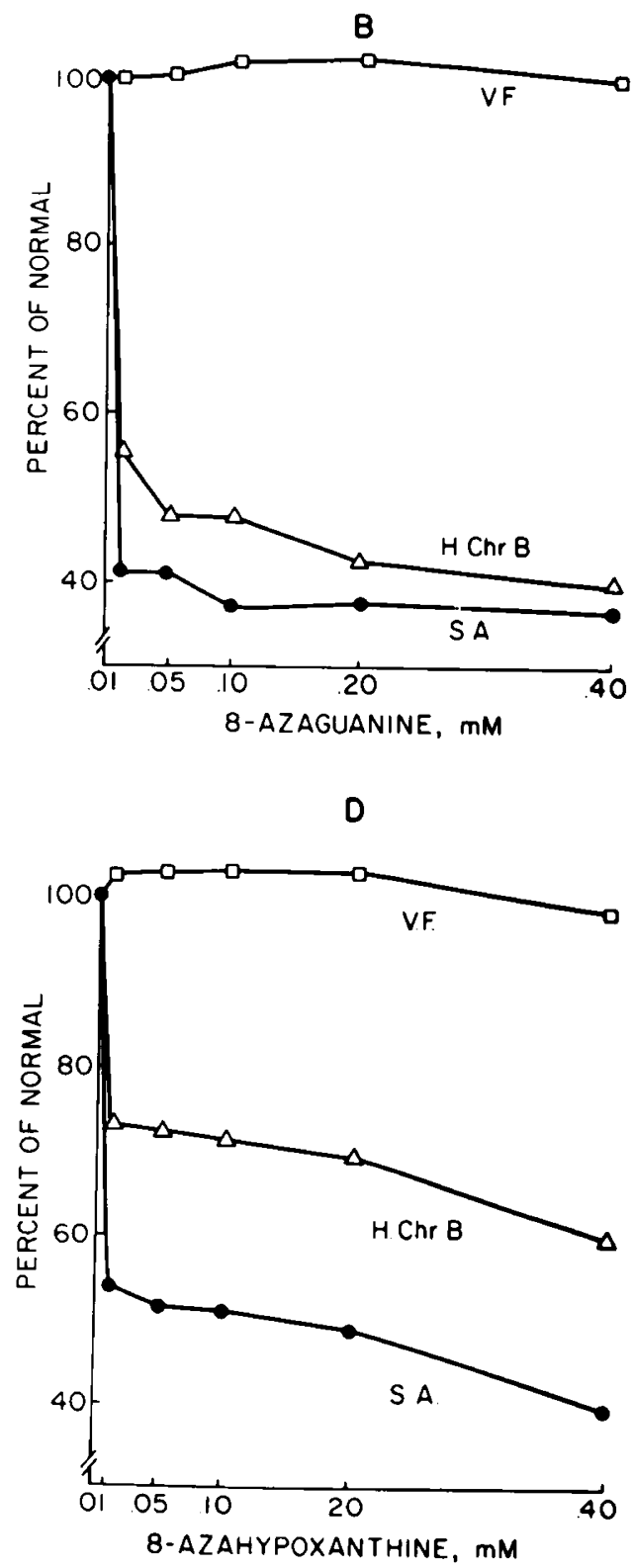

Fig. 1. Growth of cells in selective media: $A$ : Cells of a normal individual S.A., a patient with the Lesch-Nyhan syndrome V.F., and H.Chr.B. were grown in HAT medium. The plotted points represent an average count of four plates. $B, C$, and $D$ : Cells of a normal control $\mathrm{S}$.A., a patient with the Lesch-Nyhan syndrome V.F., and H.Chr.B. were grown for $72 \mathrm{hr}$ in MEM and 10\% FCS in the presence of different concentrations of 8-Aza-G, 6-TG, and $8-\mathrm{Aza}-\mathrm{Hx}$, respectively. The plotted points represent an average count of four plates. 
spectrum of clinical expressions with the Lesch-Nyhan syndrome. Certainly, the authors and others (24) have seen patients with normal or near normal intelligence whose clinical features were otherwise characteristic. However, in reported patients, the HPRT enzymes in these patients have not been characterized sufficiently to permit a decision as to whether they had the classic variant. A patient with classic features of the Lesch-Nyhan syndrome except for the lack of tendency to self-mutilation was described by Schneider et al. (25). Of course, H.Chr.B. has been frequently cited as a patient with the Lesch-Nyhan syndrome who had normal intelligence, and an absence of mutilative behavior $(8,18-$ 20). It is now submitted that he is not an example of the LeschNyhan syndrome, but representing instead a distinct variant of HPRT.

An absence of enzymatic activity as in patients with the LeschNyhan syndrome may reflect an alteration in the primary structure which interfers with the catalytic site (4). Another possibility is that of an unstable enzyme. Within the Lesch-Nyhan syndrome, genetic variation has been documented by McDonald and Kelley (21) in a patient with the syndrome who had a variant HPRT with altered kinetic properties. Two patients were reported by Dancis et al. (9) in whom there was no HPRT activity in erythrocytes, but there was functional HPRT enzyme in leukocytes. One patient had essentially normal activity in intact cells but no activity in cell lysates, whereas another patient had activity in lysates but no activity in intact cells (13). Certainly in H.Chr.B., routine analysis of hemolysates and lysates of cultured fibroblasts for HPRT, revealed no evidence of activity (19), and, in this respect, H.Chr.B. could not be distinguished from the patient with the Lesch-Nyhan syndrome. However, a more elaborate study of his hemolysates and intact cultured fibroblasts produced evidence for the presence of substantial HPRT activity and suggests that the HPRT variant of H.Chr.B. is unstable. In fact, systematic study of purine metabolism of this patient indicated the presence of a unique variant of HPRT. Its properties are as follows: (1) Due to its instability, it shows virtually no activity in lysates of cultured fibroblasts, and of erythrocytes; (2) it is active in the intact fibroblasts and its activity in the intact cell distinguishes it clearly from the HPRT of patients with the Lesch-Nyhan syndrome; (3) it is considerably more active at high concentrations of hypoxanthine and guanine than at low $(\mathrm{Km})$ concentrations; (4) in the intact cells, it has considerably better efficiency in the handling of guanine than of hypoxanthine; and (5) it does not react with antibody prepared against the normal enzyme.

These findings have relevance to the clinical expression of the mutant gene. Experience with a number of different variants with subtle differences in expression may permit the dissection of the molecular components of the various clinical expressions in HPRT deficiency. In H.Chr.B., significant affinity of HPRT for guanine maintained the availability of nucleotides during critical stages of development, and may have prevented mental retardation and self-mutilation.

\section{REFERENCES AND NOTES}

1. Bakay, B.: Detection of radioactive components in polyacrylamide gel disc electropherograms by automated mechanical fractionation. Analyt. Biochem., 40: (1971).

2. Bakay, B., Becker, M. A., and Nyhan, W. L.: Reaction of antibody to normal human hypoxanthine phosphoribosyltransferase with products of mutant genes. Arch. Biochem. Biophys., 177: 415 (1976).

3. Bakay, B., Nissinen, E., and Sweetman, L.: Analysis of radioactive and nonradioactive purine bases, nucleosides and nucleotides by high-speed chromatography on a single column. Analyt. Biochem. 86: 65 (1978)

4. Bakay, B., and Nyhan, W. L.: Electrophoretic properties of hypoxanthine guanine phosphoribosyltransferase in erythrocytes of subjects with Lesch-Nyhan syndrome. Biochem. Genet., 6: 139 (1972).

5. Bakay, B., Nyhan, W. L., Fawcett, N., and Kogut, M.D.: Isoenzymes of hypoxanthine-guanine phosphoribosyl transferase in a family with partial deficiency of the enzyme. Biochem. Genet., 7: 73 (1972).

6. Bakay, B., Telfer, M. A., and Nyhan, W. L.: Assay of hypoxanthine-guanine and adenine phosphoribosyl transferases. A simple screening test for the LeschNyhan syndrome and related disorders of purine metabolism. Biochem. Med., 3: 230 (1969).
7. Benke, P. J., and Herrick, N.: Azaguanine resistance as a manifestation of a new form of metabolic overproduction of uric acid. Amer. J. Med., 52: 547 (1972).

8. Catel, V. W., and Schmidt, J.: Über familiäre gichtische Diathese in Ver bindung mit zerebralen und renalen Symptomen bei einen Kleinkind. Dtsch. Med. Wschr., 84: 2145 (1959).

9. Dancis, J., Yip, L. C., Cox, R. P., Piomelli, S. and Balis. M. E.: Disparate enzyme activity in erythrocytes and leukocytes: a variant of hypoxanthine phosphoribosyltransferase deficiency with an unstable enzyme. J. Clin. Invest.. 52: 2068 (1973).

10. Emerson, B. T., and Thompson, L.: The spectrum of hypoxanthine guanine phosphoribosyl transferase deficiency. Quart. J. Med.. 42: 423 (1973).

11. Francke, U., Bakay, B., and Nyhan, W. L.: Detection of heterozygotes for the Lesch-Nyhan syndrome by electrophoresis of hair root lysates. J. Pediatr., 82: 472 (1973).

12. Henderson, J. F., Fraser, J. H., McCoy, E. E.: Methods for the study of purine metabolism in human cells in vitro. Clin. Biochem., 7: 339 (1974).

13. Holland, M. J. C., DiLorenzo, A. M., Dancis, J., Balis, M. E., Yü, T. F. and Cox, R. P.: Hypoxanthine phosphoribosyl-transferase activity in intact fibroblasts from patients with X-linked hyperuricemia. J. Clin. Invest., 57: 1600 (1971).

14. Kelley, W. N., Greene, M. L., Rosenbloom. M.. Henderson, J. R. and Seegmiller. J. E.: Hypoxanthine-guanine phosphoribosyltransferase deficiency in gout. Ann. Intern. Med., 70: 155 (1969).

15. Kelley, W. N., and Wyngaarden, J. B.: The Lesch-Nyhan syndrome, In: J. B. Stanbury, J. B. Wyngaarden, and D. S. Fredrickson: The Metabolic Basis of Inherited Disease. p. 1011 (McGraw-Hill, New York, 1978).

16. Kogut, M. D., Donnell, G. N., Nyhan, W. L.. and Sweetman, L.: Disorder of purine metabolism due to a partial deficiency of hypoxanthine guanine phosphoribosyl transferase. Amer. J. Med., 48 : 148 (1970).

17. Lesch, M., and Nyhan. W. L.: A familial disorder of uric acid metabolism and central nervous system function. Amer. J. Med., 36: 561 (1964).

18. Manzke, H.: Hyperuricämie mit Cerebralparese. Syndrom eines hereditären Purinstoffwechselleidens. Helv. Paediat. Acta, 22: 258 (1967).

19. Manzke, H.: Variable Espressivität der Genwirkung beim Lesch-Nyhan-Syndrom. Dtsch. Med. Wschr., 101: 428 (1976).

20. Manzke, H., Harms, D., and Dörner, K.: Zur Problematik der Behandlung der kongenitalen Hyperurikämie. Mschr. Kinderheilk.. 119: 424 (1971).

21. McDonald, J. A., and Kelley, W. N.: Lesch-Nyhan Syndrome: Altered kinetic properties of mutant enzyme. Science, 171: 689 (1971).

22. Nyhan, W. L.: Genetic heterogeneity at the locus for hypoxanthine-guanine phosphoribosyltransferase. Ciba Found. Symp., 48: 65 (1977).

23. Richardson, B. J., Ryckman, D. L., Komarnicki, L. M., and Hamerton, J. L.: Heterogeneity in the biochemical characteristics of red blood cell hypoxanthine-guanine phosphoribosyl transferase from two unrelated patients with the Lesch-Nyhan syndrome. Biochem. Genet., 9: 197 (1973).

24. Scherzer, A. L., and Ilson, J. B.: Normal intelligence in the Lesch-Nyhan Syndrome. Pediatrics, 44: 116 (1969).

25. Schneider, W., Morgenstern. E., and Schindera, I.: Lesch-Nyhan-Syndrom ohne Selbstverstümmelungstendenz. Dtsch. Med. Wschr., 101: 167 (1976).

26. Seegmiller, J. E.: Disease of Purine and Pyrimidine Metabolism, In: P. K. Bondy and L. E. Rosenberg: Duncan's Disease of Metabolism. p. 655 (W. B. Saunders. Philadelphia, 1974).

27. Seegmiller, J. E.: Inherited deficiency of hypoxanthine-guanine phosphoribosyltransferase in X-linked uric aciduria (the Lesch-Nyhan syndrome and its variants). Adv. Hum. Genet., 6: 75 (1976).

28. Seegmiller, J. E., Rosenbloom, F. M., and Kelley, W. N.: An enzyme defect associated with a sex-linked human neurological disorder and excessive purine synthesis. Science, 155: 1682 (1967).

29. Sweetman. L., Borden, M., Lesh, P., Bakay, B., and Becker, M. A.: Diminished affinity for purine substrate as a basis for gout with mild deficiency of hypoxanthine guanine phosphoribosyl transferase. Adv. Exp. Med. Biol. 76A: 361 (1977).

30. Sweetman, L., Hoch, M. A., Bakay, B., Borden, M., Lesh, P. and Nyhan, W. L.: A distinct human variant of hypoxanthine guanine phosphoribosyl transferase. J. Pediatr., 92: 385 (1978).

31. Szybalski, W., Szybalska, E. H., and Ragni, G.: Genetic studies with human cell lines. Nat. Cancer Inst. Monogr., $7: 75$ (1962).

32. Vaughan, M. H., and Steele, M. W.: Differential sensitivity of human normal and malignant cells to 8-azahypoxanthine in vitro. Exptl. Cell Res.. 69: 92 (1971).

33. Willers, I., Held, K. R., Singh. S., and Goedde, H. W.: Genetic heterogeneity of hypoxanthine-phosphoribosyl transferase in human fibroblasts of 3 families. Clin. Genet., 11: 193 (1977).

34. The authors thank Margaret Borden and Kathy A. Nicolaisen for their competent help and Dr. Hermann Manzke for providing blood specimens.

35. This research was supported by United States Public Health Service grants no. HD-04608, GM-17702 from the National Institutes of Child Health and Human Development and General Medical Sciences, National Institutes of Health, Bethesda, Maryland, grant no. MCT-004007 from Department of Health, Education and Welfare, Maternal and Child Health Service, Rockville, Maryland, and Grant No. NF-1377 from the National Foundation, March of Dimes.

36. Requests for reprints should be addressed to: Dr. Bohdan Bakay, Department of Pediatrics, University of California, San Diego, La Jolla, California 92093, USA

37. Received for publication June 15, 1978

38. Accepted for publication January 11, 1979. 